Open Access

\title{
Developing stereotypes to facilitate dialogue between social entrepreneurs and local government
}

Maarten Hogenstijn * D, Martha Meerman and Joop Zinsmeister

\author{
* Correspondence: \\ m.hogenstijn@hva.nl \\ Amsterdam University of Applied \\ Sciences, Centre for Applied \\ Research on Economics and \\ Management, Wibautstraat 3B, PO \\ Box 1025, Amsterdam 1000 BA, The \\ Netherlands
}

\begin{abstract}
Social enterprises and government share the ultimate goal of solving societal problems, which provides a lot of potential for collaboration between the two parties. While the local government level is the most relevant for social enterprises, little research has been done on the relationship between social entrepreneurs and local government officials. However, in the Netherlands, social enterprises experience these relations as far from optimal, evidenced by the fact that they named 'regulations and government policy' as the most important obstacle for increasing their impact in a 2015 sector survey. Therefore, a pilot project was started with social entrepreneurs in an Amsterdam neighbourhood, forming a learning network aiming to improve relations with local government. In the network, an innovative tool was developed in the form of a set of five illustrated stereotypes of social entrepreneurs with certain views towards local government. These stereotypes serve both as a reflection tool for social entrepreneurs and as a communication tool to open dialogue between social entrepreneurs and local government. We conclude that in an applied research project, it is crucial to place focus on the final phases in which results are reformulated into practical tools to match target groups, and resulting tools are distributed through targeted events and publications.
\end{abstract}

Keywords: Social entrepreneurship, Social enterprises, Local government, Applied research, Learning network, Stereotypes

\section{Introduction}

Social entrepreneurs and government share the ultimate goal of solving societal problems. In theory, this means that there is a great potential for social enterprises and government to form partnerships and collaborate in various ways. In practice, this often proves problematic. Governments find it hard to handle the hybridity of social enterprises, which have a problem-solving mission but also need to run a sustainable business, or do not recognise their role in problem-solving. Misunderstandings are common. In this article, we focus on the results of a pilot project with a group of social entrepreneurs in Amsterdam, the Netherlands. The entrepreneurs formed a learning network, focusing on efficient and effective ways to cooperate with the local government. The aim of this applied research project was also to develop research-based tools to facilitate dialogue between social entrepreneurs and local government.

(c) The Author(s). 2018 Open Access This article is distributed under the terms of the Creative Commons Attribution 4.0 International License (http://creativecommons.org/licenses/by/4.0/), which permits unrestricted use, distribution, and reproduction in any medium, provided you give appropriate credit to the original author(s) and the source, provide a link to the Creative Commons license, and indicate if changes were made. 
To understand the background and context of our research, we briefly explain our view towards the concept of social entrepreneurship, some particularities of the Dutch context, and the problem that was identified in the relationship between social enterprises and local government, which forms the reason to start this research project. We then discuss the methods and results, focusing on the practical application of the tools that were developed in our project.

\section{Background}

As applied researchers, our main aim in this project was to find practical researchbased solutions for a real-world problem encountered by social entrepreneurs in the Netherlands.

The starting point for this research was a result from the 2015 Social Enterprise Monitor, which is the best sector overview available in the Netherlands. The Monitor is produced annually from a membership survey by national platform organization Social Enterprise NL, which exists since 2012. Using relatively strict criteria for full membership (such as a minimum annual turnover of $€ 150,000$ ), it has grown to over 300 members. In the 2015 Monitor, social entrepreneurs named 'regulations and government policy' the main obstacle for the enlargement of their societal impact (Social Enterprise NL 2015, p. 6). This was the starting point for this research project, aiming to find ways to cope with this obstacle.

The first step was then to find a work definition for social entrepreneurship. Interest in social entrepreneurship has grown exponentially over the last decade, as shown for example in the Global Entrepreneurship Monitor surveys (Bosma et al. 2016, p. 2). The fast-growing body of literature on this subject shows it is a hybrid concept in many ways. A social enterprise works to solve societal problems, while at the same time, it needs to be a viable business. More and more often businesses identify themselves as social enterprises, while at the same time, this is a hotly contested concept in scientific literature. There are dozens of definitions (Dacin et al. 2010, p. 38-42; Teasdale 2012; Kraus et al. 2014), which are heavily debated (see for example Peredo and McLean 2006; Martin and Osberg 2007; Defourny and Nyssens 2010; Abu-Saifan 2012; Kickul and Lyons 2016). This has led Choi and Majumdar (2013) to call social entrepreneurship an 'essentially contested concept', for which it is virtually impossible to find a common definition.

While the definition discussion is very relevant in many ways, it is not at the core of our work as applied researchers. We therefore follow Choi and Majumdar on their way out of the definition discussion by approaching social entrepreneurship as a 'cluster concept', consisting of several sub-concepts: 'According to this understanding, social entrepreneurship can be viewed as a conglomerate of several sub-concepts which are identified as (1) social value creation, (2) the social entrepreneur, (3) the social entrepreneurship organization, (4) market orientation and (5) social innovation' (Choi and Majumdar 2013, p. 364).

Of these five sub-concepts, only social value creation is a necessary condition for social entrepreneurship. Other sub-concepts come into play depending on the goal of the research and the disciplinary lens chosen. Our goal is to help improve cooperation between social enterprises and government in the Netherlands, which is mainly related to the organizational dimension of social entrepreneurship (sub-concept 3). We adopt a 
broad work definition that was developed for the Dutch context by the Social and Economic Council of the Netherlands (SER): 'Social enterprises are independent companies who produce goods and services and primarily and explicitly strive for a societal goal, i. e., they want to solve a societal problem' (SER 2015, p. 26, own translation). The social value created by social enterprises is generally described with the word impact, and the societal goal of the value creation process is called impact area.

The relationship between social entrepreneurship and government also has elements of hybridity (Doherty et al. 2014). On the one hand, social enterprises frequently appear where the governments fail to provide for social needs (Stephan et al. 2015), and government activism is negatively correlated with social entrepreneurial start-up efforts (Estrin et al. 2013). On the other hand, activities of social enterprises can be highly dependent upon governmental regulations and/or government support in various forms, including normative and cultural-cognitive components (Terjesen et al. 2016).

Essentially, social enterprises and government have the same ultimate goal of solving societal problems, but they apply different organizational logics (see also Smeets 2017). Schulz et al. (2013) have summarised these different logics (Table 1).

While legal boundaries and regulations for social entrepreneurship are usually set at the national level, relations with the government at the local level are most important for social enterprises. In a comparative research project spanning 11 countries, the European Commission found that in all countries, 'local authorities are pivotal actors in the development of a supportive social enterprise ecosystem. (....) Local authorities have such a preeminent role in the configuration of the social enterprise ecosystem primarily because they provide opportunities for social entrepreneurship in conjunction with social services or delivery of state health and welfare services. In contrast, social entrepreneurs regard national governments as beyond their reach and influence' (European Commission 2015, p. 2).

While the importance of the relationship between social enterprises and local government is thus recognised, research on the nature of this relationship has mainly focused on the hybridity of organizational forms (Doherty et al. 2014), the measurement of performance of social enterprises with local government as stakeholder (Blundel and Lyon 2015; Crucke and Decramer 2016) and the embeddedness of local policies towards social entrepreneurship in the broader national policy context, often with special focus on the British perspective (Defourny 2014; Ridley-Duff and Bull 2015; Sepulveda 2015). In a study on the relationship between the public sector at different levels and social entrepreneurship in Sweden, Gawell finds 'a negotiation of emerging markets in which both services but also relationships are negotiated' (Gawell 2014, p. 264).

Table 1 Logics applied by government and social entrepreneurs

\begin{tabular}{lll}
\hline Aspect & Logic government & Logic social entrepreneur \\
\hline Government involvement & $\begin{array}{l}\text { Needed at start of initiative, to get it } \\
\text { going }\end{array}$ & $\begin{array}{l}\text { Needed when initiative is running and } \\
\text { needs to be made sustainable }\end{array}$ \\
Role of government & Select promising initiatives & Follow and participate in own initiatives \\
Focus of government & Stimulate, provoke and help to get going & Subvene, take over when needed \\
Timing of government role & Release and withdraw after a few years & $\begin{array}{l}\text { Take up and hold after a few years of } \\
\text { independence }\end{array}$ \\
& &
\end{tabular}


However, returning to our goal of helping to improve the cooperation between social enterprises and local government in the Netherlands, we found extant literature lacking in providing practical tools. In a rare study focusing on the municipal level, Korosec and Berman (2006) proposed some possible solutions, both in the form of technical tools that facilitate collaboration and in coordination and communication efforts. However, most solutions offered so far are not really viable for small-scale social enterprises. The technical tools are often too complicated. For example, social impact bonds, which form an innovative financial solution encouraging collaboration between social enterprises, regular companies and local government, have found their way into the Netherlands in recent years, but managing these bonds is very complicated and resource-consuming (Smeets 2017).

The communication solutions presuppose a basic mutual understanding between social enterprises and local government that we found to be often still lacking in the Dutch context. Therefore, we decided to focus our project on the development of (mutual) understanding.

To understand the lack of mutual understanding in the Dutch context, it is relevant to briefly discuss the development of the social entrepreneurship sector in the Netherlands. The country is still considered to be lagging behind at the European level (European Commission 2014). The sector is small. A 2016 report by McKinsey estimated the number of social enterprises in the Netherlands at 5000-6000, the number of jobs created at 65,000-80,000 and the total turnover at 3.5 billion euros, or $0.3 \%$ of the Dutch GDP (Keizer et al. 2016, p. 5).

The Netherlands is one of the few European countries without a national policy on social entrepreneurship (European Commission 2014, p. 50-52), although some development is visible in recent years. The government first ordered a report listing good practices in other countries (Arnoldus et al. 2013) and subsequently asked the SER, one of their most important advisory bodies, to write a report on the sector. After the report was published (SER 2015), the government took over a year to respond, but their response (Ministerie van Sociale Zaken en Werkgelegenheid 2016) still fell short of formulating a policy. In late 2017, the new national government wrote a single sentence relating to social entrepreneurship in its coalition agreement, stating that appropriate rules will be drawn up and more scope will be created for businesses whose goals relate to civil society' (People's Party for Freedom and Democracy (VVD), Christian Democratic Alliance (CDA), Democrats '66 (D66) and Christian Union (CU) 2017, p. 36). While the statement was viewed as an important milestone by the sector, it had not yet led to the formulation of actual policy by February 2018.

There is no legal definition for social enterprises either. The government's view is that it is up to the sector to take the initiative to create a 'label' for social enterprises that helps to distinguish 'real' social entrepreneurs from others. Indeed, the sector is developing a 'code' for social enterprises, in a process initiated by the national platform organisation Social Enterprise NL. The intention is to set up a register for companies which follow a set of guiding principles while safeguarding adherence to the code by a peer review system (Commissie Code Sociale Ondernemingen 2017).

With national policies and a legal framework lacking, there is room for local policies on social entrepreneurship. This has led to vast differences between municipalities, with some developing a strong support policy, while others have no support mechanisms 
whatsoever. Among the larger cities, Utrecht and Amsterdam are considered frontrunners in stimulating social entrepreneurship (Keizer et al. 2016, p. 7). Following a council initiative, the municipality of Amsterdam has developed the action program social entrepreneurship 2015-2018 (Oetelmans 2015), with the ultimate aim of becoming the leading place in the Netherlands for social entrepreneurship. The municipality also executes a separate work plan to stimulate Work Integration Social Enterprises (Gemeente Amsterdam 2015a). In addition, it has included social return in its public procurement process since 2008 (Gemeente Amsterdam 2016). This means that in every contract given out, the municipality requires the contractor to contribute to the participation of people with difficult labour market positions or to other activities with social impact in Amsterdam. Usually, this requirement is for the 5\% of the total contract amount. Potentially, this could lead to a lot of work for social enterprises, but in practice, social return requirements have been filled in through other channels for years and social enterprises are just starting to make use of this opportunity.

In our broader research project in the Netherlands, we found that the local government performs four roles for social enterprises:

1. Regulator

2. Funder

3. Customer

4. Participant

(Hogenstijn et al. 2016, p. 6-7; partly based on Schulz et al. 2013, p. 44)

There are a number of potential problems in the performance of these roles. First, different roles can be conflicting, for example, when the execution of a policy promoting the municipality to act as 'launching customer' for new social enterprises is hindered by the 'fair play' rules of public procurement. Second, even within the same role, different branches of the local government each have their own policy goals, and internal cooperation is often lacking.

Third and related to this, the local government finds it difficult to deal with the innovative hybrid business models of social enterprises, which combine social goals with running a business. In the municipal organisation, these goals are met by different branches of the organisation. A fourth and final problem is the lack of a common language. The words which are used by social entrepreneurs to describe their organisations and the goals they want to achieve often do not match the words which are used by government officials to describe policy aims. These words and aims can also change with political changes in the election cycle. In addition, social entrepreneurs sometimes also lack insight into the government organization and look at government as a single entity. This can lead to disappointment, for example, when they see that a policy by the economics department to encourage and support social entrepreneurs is not followed by the purchasing department. In the words of one of the participants in our project:

It would be great if local government supported us more, for example by buying our products and services. This is also part of their policy. (...) But in practice, it does not work. 
To improve relations between social entrepreneurs and local government in Amsterdam, we would first need more insight into the exact problems that were experienced by social entrepreneurs and possible solutions. Adopting an inductive approach, we decided to organise a 'learning network', inviting social entrepreneurs that are active in the impact area of labour market participation to join. In the learning network, we worked from the main research question: In what ways can social enterprises and local government collaborate to make an impact on the solving of societal problems in the impact area of (labour market) participation?

\section{Methods}

Doing research on an 'essentially contested concept' such as social entrepreneurship is not straightforward. Indeed, as Fossati et al. (2017) found, 'researchers are placed in a very peculiar epistemological position, as they need to make sense of the contested character of the concept' (p. 49). They propose a pragmatic approach to methodological choices, which we follow here. Our point of departure is that we are applied researchers doing a pilot project in a restricted geographical area, aiming to gain new information on a current issue in order to help us develop tools to bring this issue forward. At the same time, we are fully aware that the restricted nature of our pilot project will lead to results that cannot be generalised beyond the specific area studied and should mainly be seen as an invitation for further research.

To optimise the potential learning effect of our pilot study, we chose the form of a learning network. A learning network consists of individuals who are willing to exchange expertise and experiences and to search collectively for new insights, aimed at sustainable changes in knowledge, attitude, competences and the capacity to learn (De Laat et al. 2001; Zinsmeister 2012).

Networks and communities can create value when used for social learning activities (Wenger et al. 2011) and learning networks of small and medium-sized enterprises are known to have the potential to improve companies' strategic capabilities (McGovern 2006). A university-driven learning network can act as an arena for joint reflection, support and as a resource pool (Tell and Halila 2001). Providing a platform for mutual learning (Penman and Ellis 2003) was therefore valuable in itself for those involved in the learning network, although the main aim was to facilitate the development of tools to improve relations with local government.

In the process of organizing the learning network, we took a 'bottom-up' approach, starting from the needs of the social entrepreneurs. This implied that different methodological questions were left to be resolved during the course of the learning network. At the start, it was still open whether government officials would also participate in the network and what the final product would be.

The project was set up in Amsterdam New-West, a sub-municipality of the Dutch capital Amsterdam, with around 145,000 inhabitants. This area is located in between the Port of Amsterdam and Schiphol Airport and is characterised by relatively low income, low labour participation rate and a high level of ethnic diversity (Gemeente Amsterdam 2015b, pp. 27-30; 176).

The area of Amsterdam New-West was chosen mainly for practical reasons; through earlier research projects (for example Ballafkih et al. 2016), Amsterdam University of 
Applied Sciences (UAS) had a lot of existing contacts with local entrepreneurs, societal organisations and local government.

We decided that the most important first step was to gain insight into the problems experienced and solutions offered from the side of the social entrepreneurs and therefore focused on creating a safe environment for their participation in the learning network. The network was eventually formed with eight companies, who are all active in the impact area labour market participation within Amsterdam New-West.

We used a six-step approach for the process of setting up, running and evaluating the learning network. The main goal, as was also communicated to all involved, was to analyse current difficulties and help facilitate a better relationship between social entrepreneurs and local government. At the start of the project, the end product which would facilitate this better relationship was not yet defined in detail. The project started in March 2016; the final project presentation was in March 2017.

\section{Step 1: Recruitment and intake}

The first step was to recruit social enterprises and set up the network. A list of 32 possible social enterprises was compiled, based on a combination of an inventory done by a local network organisation subsidised by the Amsterdam municipality and our own Amsterdam UAS network. From this list, we made the first selection of 16 entrepreneurs that were to be approached by the research team. The intention was to make a heterogeneous selection of approximately ten enterprises of different size and type of activities.

Out of the 16 companies approached, 6 did not join for various reasons, mainly because they were unable to invest the time required. Ten companies were selected and willing to join, and with these companies, a date for the first learning network was set.

During intake, social entrepreneurs were asked their opinion about possible participation in the learning network by local government officials. Reactions were ambivalent. While some entrepreneurs welcomed their participation, others said that they might not speak freely about their problems if officials were to be present. Therefore, it was decided not to include government officials in the first meeting, as this could hinder the essential process of building mutual trust (Bergh et al. 2011) in the learning network.

Shortly before the first meeting, two companies dropped out because of practical reasons. The first meeting was therefore held with eight companies.

\section{Step 2: First exchange}

The aims of the first learning network meeting were to get to know each other and to exchange experiences in dealing with the local government. Participants were asked beforehand to reflect on their companies' relations with the local government in its different roles. A lively discussion followed, focusing on topics such as the entrepreneurs' motivation, their connection to local communities, cooperation with government and NGOs and their companies' roles in procurement processes. At the end of the meeting, it was decided that this group composition provided good dynamics and mutual trust and therefore would remain the same for the rest of the project. In addition, participants were given a 'homework assignment' to develop a scenario for 
the ideal form of cooperation with the local government, using the method developed by Zinsmeister (2012).

\section{Step 3: Second exchange}

The second learning network meeting was planned 5 weeks later. The aim of this meeting was to develop practical ideas for better cooperation with local government, using the scenarios (from step 2) as a basis. At the meeting, only five out of eight companies were present and four had completed the scenario, with the others citing time restrictions or other practical reasons for not showing up at the meeting and/or completing the scenario. Still, a constructive discussion (lasting 2 hours) followed, in which the participants reacted on each other's scenarios and went in-depth on preconditions and strategies for realising the scenarios. After the meeting, short (recorded) telephone interviews were held with the three companies not present to ask their opinions on the themes under discussion and the practical ideas developed.

\section{Step 4: Preliminary analysis}

In this phase, we analysed the transcriptions of the first two meetings, the scenarios plus the intake and telephone interviews, using a qualitative research software package [MAXQDA]. We started with a phase of deductive coding and subsequently complemented this with inductive coding. We structured the analysis into three main parts:

1. Entrepreneurs' past experiences of dealing with local authorities;

2. Strategies they now use towards authorities;

3. Scenarios for a better collaboration in the future.

Individual participants were also assigned labels. Combining the individual labels and content labels, an analysis was made of the relations between labels at the group level and subsequently also at the individual level. A lack of common understanding of intentions and goals was identified as an overall theme.

This inductive approach inspired the development of a set of five stereotypes of social entrepreneurs in relation to local government as a practical tool to improve understanding (see the 'Results' section). Going back to the literature on stereotypes, we then tried to find a form suiting our goal. The process of stereotyping has been extensively studied in (social) psychology. Traditionally, it is often labelled negatively and described as a process with 'victims' and 'perpetrators' (for example Major and O'Brien 2005), focusing on the inaccuracy of stereotypes. This is also the approach to stereotypes and stereotyping generally found in entrepreneurship research, where it is mostly used in relation to gender roles (see for example Gupta et al. 2009). However, other scholars argue for the opposite, claiming that 'stereotype accuracy is one of the largest and most replicable findings in social psychology' (Jussim et al. 2015). Another body of literature revolves around the 'kernel of truth hypothesis' (Prothro and Melikian 1955), which poses that 'stereotypes are based on some empirical reality. As such, they are useful but may entail exaggerations' (Bordalo et al. 2016, p. 3). Stereotypes are then 'no more illogical or erroneous than generalizations about any other sort of category that perceivers might construct and find useful' (Judd and Park 1993, p. 109). 
Departing from this notion of usefulness and taking into account that stereotypes are context dependent and always relating to a reference group (Bordalo et al. 2016), we compiled stereotype descriptions using exemplary views or strategies derived from clusters of related content labels.

Preliminary descriptions of these stereotypes, the results and discussion sections of the research report and a four-page discussion document were shared with the participants 10 days before the next meeting.

\section{Step 5: Discussion and validation}

The third meeting of the learning network was held about 3 months after the second meeting. The aim of this meeting was to discuss the preliminary results, the process in the network and future steps. Seven out of eight entrepreneurs attended the meeting. Specifically for the stereotypes, participants were asked to fill out a form, scoring on a 5-point scale to what degree they recognised themselves in each of the stereotypes. When it was verified that each of the stereotypes elicited a certain degree of recognition, a discussion was initiated, focusing on three themes:

1. Completeness of the set of stereotypes (do these five stereotypes cover all possible positions, is a sixth one missing and/or can stereotypes be combined?);

2. Recognisability of the stereotypes not only in themselves but also in others;

3. Titles and descriptions of the stereotypes.

The participants agreed on the completeness of the set and the recognisability of each of the stereotypes. On the basis of the discussions, adjustments were made in titles and descriptions of two stereotypes.

\section{Step 6: Final analysis and presentation}

Taking into account the results of step 5, the full research report (in Dutch) was prepared. Subsequently, products were developed to facilitate dialogue based on the research results (see the 'Results' and 'Discussion' sections below).

\section{Results}

The ultimate aim of this applied research project was to facilitate dialogue to improve relations between social entrepreneurs and local government. Taking the entrepreneurs' point of view, we analysed their past experiences of dealing with local authorities, the strategies they now use towards authorities and their scenarios for a better collaboration in the future.

This analysis was used to develop an instrument that could help to facilitate dialogue-a set of stereotypes of social entrepreneurs with distinctive views towards (local) government.

We consider this set of stereotypes a major result of our project and one which is potentially useful to the scientific community, despite its limitations as discussed in the next section. The other results of the project, such as lists of practical tips for social enterprises and local government officials, are published in the full (Dutch language) research report (Hogenstijn et al. 2016). 
We identify the following five stereotypes of social entrepreneurs with a particular view towards (local) government (everywhere we write 'he', you can also read 'she'). These stereotypes are not intended to be mutually exclusive; an entrepreneur might feel related to different stereotypes at the same time.

1. The disappointed authority avoider

Social entrepreneurs and government are ideal partners to solve problems in our society. That used to be what this entrepreneur thought. But so far, every single one of his attempts to cooperate with the government only led to failure. In spite of this great disappointment, this entrepreneur continues with his mission. But he now chooses to avoid the authorities where possible.

2. The creative system changer

We have to radically change the system because the way we act now is not futureproof. It is this entrepreneur's deep conviction that radical change is necessary, although he realises it takes time. He takes initiatives to start the process of change and to keep it going. He is always eager to find creative ways to realise his mission.

3. The proactive problem handler

Do not waste your time talking, get to work. This entrepreneur believes in leading by example. By doing things, change starts to be made and you can make a difference in society. This entrepreneur would find it great if the government supported him in this process but prefers to keep matters in his own hands. If there is more work for his company, then he can help more people and make more of a difference in society.

4. The strategic policy follower Maintaining a good working relationship with the government is not easy, in this social entrepreneur's experience. Priorities in policies and subsidy regulations can quickly change. But a good relationship with government is crucial for this entrepreneur's business. Therefore, he follows the policy closely and tries to act strategically and proactively.

5. The networking lobbyist Working together makes everyone stronger, and a good network is essential to get things done. Those are the two principles on which this social entrepreneur acts. When talking to government officials, he pleads both the case of his own company and of the whole sector. Everywhere he comes, he makes new contacts. That does not always yield results immediately but is mainly an investment in the future.

Once the stereotypes were agreed upon in the last meeting of the learning network, we discussed their possible direct use for the entrepreneurs in the network. The research team was convinced that to facilitate dialogue, a visual representation of the stereotypes would be a welcome addition to the descriptions in words. Therefore, an artist was asked to develop illustrations for each of the stereotypes. After a briefing, sketches were prepared and discussed with the research team, and subsequently, full illustrations were made (Figs. 1, 2, 3, 4 and $5^{1}$ ).

As a next step, the stereotype illustrations and descriptions formed an important part of a 16-page brochure that was developed to give both social entrepreneurs and 


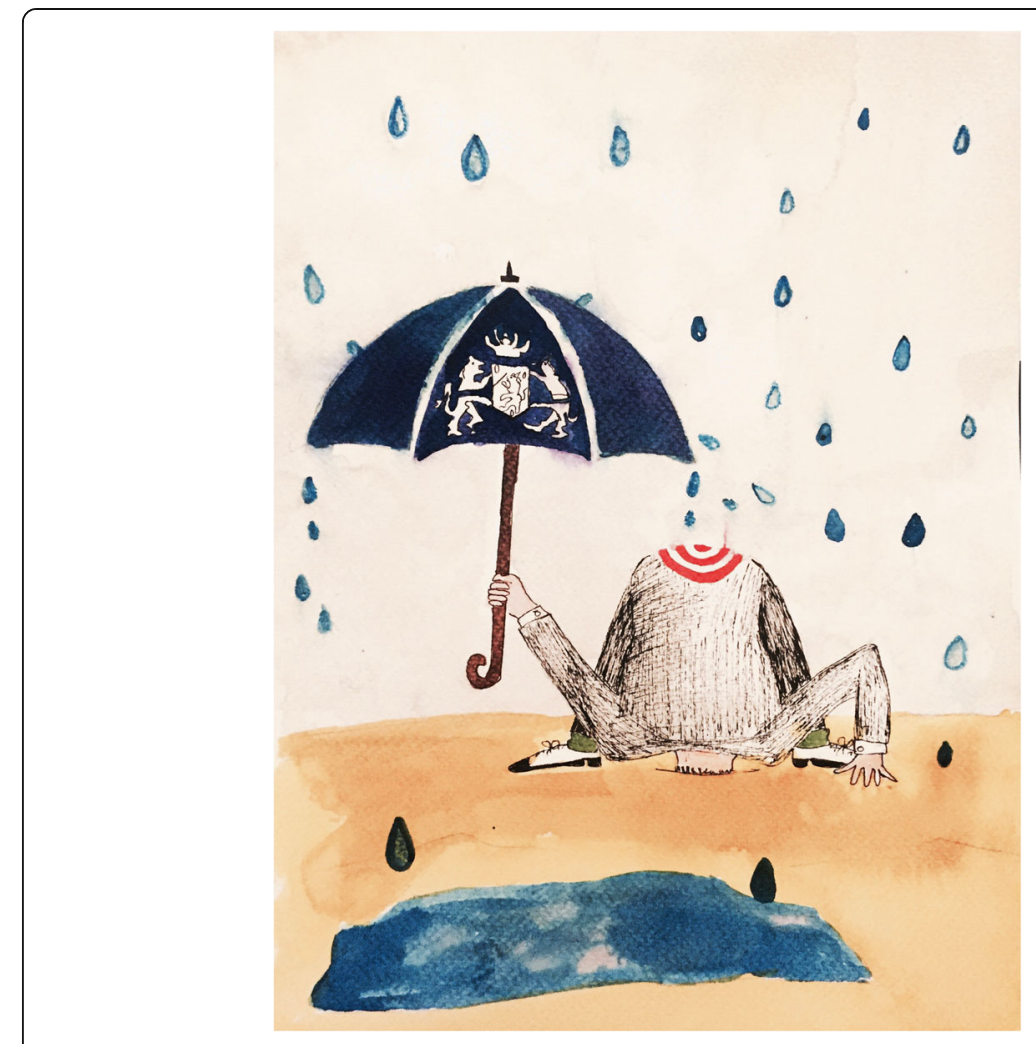

Fig. 1 The disappointed authority avoider, by artist Yara Said. Source: Hogenstijn et al. 2016, p. 38 (reprinted with permission)

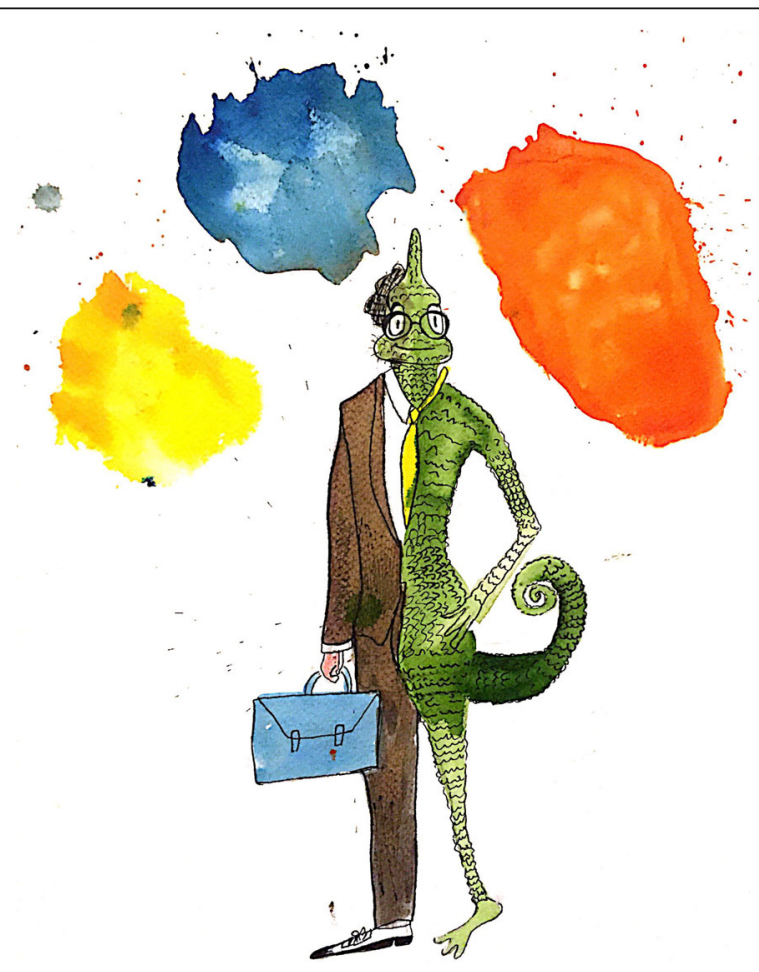

Fig. 2 The creative system changer, by artist Yara Said. Source: Hogenstijn et al. 2016, p. 39 (reprinted with permission) 


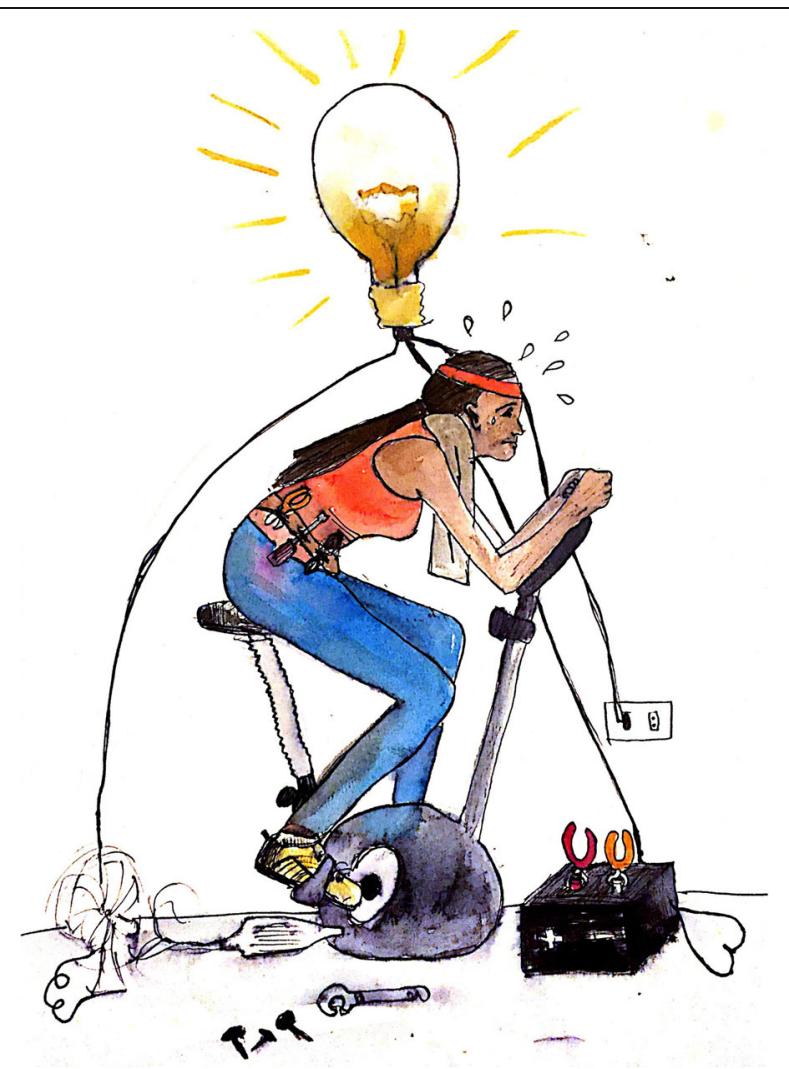

Fig. 3 The proactive problem handler, by artist Yara Said. Source: Hogenstijn et al. 2016, p. 40 (reprinted with permission)

government officials access to the research results in plain language and to encourage them to intensify collaboration. The brochure was titled Samen sociaal en ondernemend (literally: together, social and entrepreneurial) (Hogenstijn 2017). When the brochure was finished, an event was organised, bringing together social entrepreneurs, government officials and educators. Around 60 people attended this event, where the stereotypes were introduced to the audience and used to guide discussions. Afterwards, the stereotypes were used in different workshops with local government officials in Amsterdam and elsewhere.

In addition, the research team made further efforts to spread the brochures and illustrated stereotypes among a larger group of social entrepreneurs through national network organisation Social Enterprise NL (who used it in an entrepreneurship development program), by contacting various other local governments, staff of relevant ministries and other Dutch higher education institutions. At the time of writing, further distribution is still ongoing.

\section{Discussion}

What lessons can be learnt from the process in the learning network and the development of the stereotypes? In this section, first, we briefly discuss the use of stereotypes in general. We then continue to place the results into perspective by elaborating on the limitations of the study. Finally, we return to the views of the entrepreneurs in the learning network. 


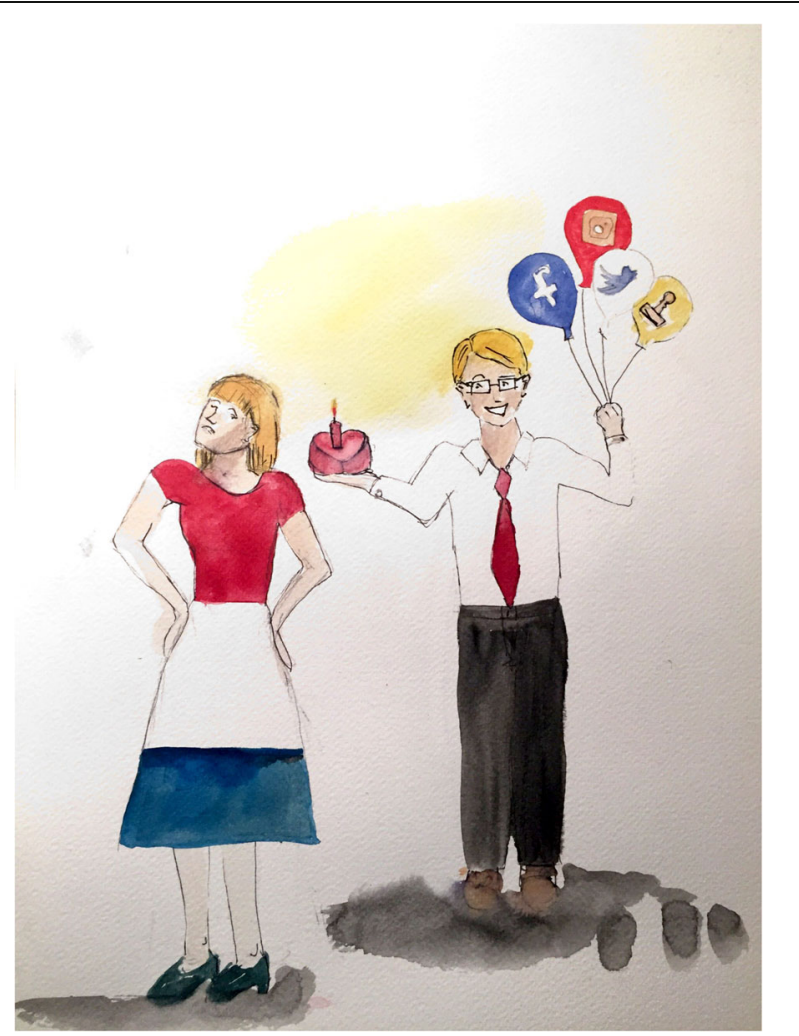

Fig. 4 The strategic policy follower, by artist Yara Said. Source: Hogenstijn et al. 2016, p. 41 (reprinted with permission)

The choice to develop stereotypes in this study was not taken in the phase of research design. Instead, it was a choice made at the point where interim results from the learning network were analysed, and the clustering of codes inspired this direction for the development of a practical tool.

This was not an easy option, as we are aware that the concept of stereotypes and the process of stereotyping has negative connotations for some. However, we take courage from research showing that stereotypes are especially useful in situations in which a stereotype is highly diagnostic (Crawford et al. 2011). In addition, they are shown to have an impact in situations when the available individuating information is lacking or ambiguous (Kunda and Thagard 1996). In a literature review, Jussim et al. 2015concluded that 'the more diagnostic individuating information people have, the less they stereotype (...) Thus, people do not indiscriminately apply their stereotypes to all individual members of stereotyped groups' (p. 494). Consequently, we think stereotypes can be useful when first encountering a new group, and its application does not mean that stereotypes are subsequently used for all individuals. In our case, the phenomenon of social entrepreneurs is new to a lot of local government officials, and we think that the stereotypes can help them to start thinking about this group.

However, the stereotypes developed in this study also have severe limitations. This research project was set up as a pilot project, aiming to develop ideas based on experiences gathered in a non-randomly selected learning network of social entrepreneurs. We did not aim for theorisation or for tools with general applicability, but rather for tools that have the potential to encourage dialogue between social entrepreneurs and 


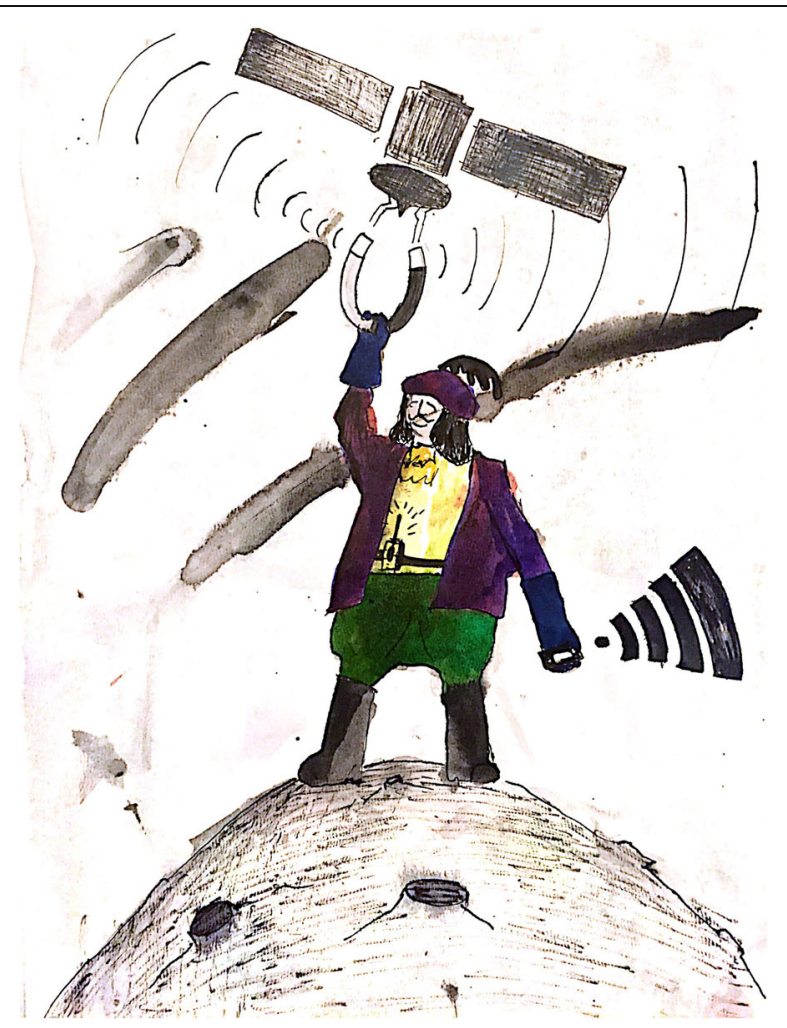

Fig. 5 The networking lobbyist, by artist Yara Said. Source: Hogenstijn et al. 2016, p. 42 (reprinted with permission)

government officials. The stereotypes that were developed are therefore based on a limited range of experiences of social entrepreneurs that are active in Amsterdam NewWest in the impact area of labour market participation. This small basis implies that research outcomes are not generalizable. We think that a large-scale survey or a randomised sample can yield better results; however, we are also aware that setting up such types of research with entrepreneurs can be a daunting task. We therefore do hope our results can still be a useful starting point for research in other contexts or impact areas.

Another major limitation of this study is that the learning network was only formed with social entrepreneurs and not with government officials. Although this was a choice explicitly made in steps 1 and 2 of the research plan, it implies that the usefulness of the stereotypes among government officials is highly dependent upon the researchers' abilities to describe them in terms that are sufficiently familiar to this target group. We do recommend that both groups be brought together in future research.

To conclude this section, how do the participants in the learning network themselves-given the limitations above-see the usefulness of the stereotypes? They saw two main forms of use, for themselves and for government officials respectively. We illustrate each type of use with a quote from the discussion in research step 5 :

1. Mirror for social entrepreneurs.

The stereotypes work like a mirror for me. I now see that in my company I have played a specific role, without thinking about this. I now realise I could also play a different role and that this could have advantages. 
2. Improved understanding among government officials.

I think it is very useful to show local government that social entrepreneurs can take different approaches.

Both types of use have been put to practice in step 6 of the research project, and this process is still ongoing. However, the focus has been mostly on either social entrepreneurs or government officials. The challenge ahead is to use the stereotypes in a direct dialogue between the two groups, in order to help social entrepreneurs and local authorities to collaborate more closely.

\section{Conclusions}

The aim of this pilot project was to develop research-based tools to facilitate dialogue between social entrepreneurs and local government, in order to find a solution for the problem that social entrepreneurs in the Netherlands perceive 'government and regulations' as a major barrier for the enlargement of their societal impact. To achieve this, we have formed a learning network with eight social enterprises in Amsterdam NewWest, which are all active in the impact area of labour market participation. Experiences in the learning network have yielded interesting lessons, both with regard to content and with regard to the process.

Content-wise, we have created five stereotypes of social entrepreneurs in relation to local government. Early signs indicate that these stereotypes are useful starting points for dialogue between the two parties. Once they then realise, they are both pursuing the same ultimate goal of solving societal problems, this forms an opening for collaboration.

Process-wise, we can conclude that a learning network provides a good setting to generate new ideas. The focus on a positive scenario describing an ideal relationship between social entrepreneurs and government proved very productive. At the same time, however, not too much effort can be expected from entrepreneurs in a learning network. They are in the process of running a business, and the time they can spend on a project not directly generating new income is limited. In addition, we have learned that focus on the final phase of the research project, in which results are reformulated to match target groups and distributed through targeted events, is crucial to make an impact.

Social entrepreneurs are innovative changemakers in society. A lot of targeted efforts are required for researchers to reach this same level of change making.

\section{Endnotes}

${ }^{1}$ Figures are reproduced with permission of the artist Yara Said, whose work can be found through https://nl-nl.facebook.com/Yara-Said-845028635568261/

Abbreviations

GDP: Gross domestic product; NGO: Non-governmental organisation; SER: Social and Economic Council of the Netherlands; UAS: University of Applied Sciences 


\section{Availability of data and materials}

Raw data are not openly available due to anonymisation issues. Consent from participants was obtained to use the quotes in the final report and this paper. Raw data have not been checked for the possibility of being traced back to an individual. This was considered disproportional to the size of the research project. For more information on the raw data, the corresponding author can be contacted through e-mail.

\section{Authors' contributions}

All authors contributed to the design of the research project. $\mathrm{MH}$ and JZ led the learning network meetings. $\mathrm{MH}$ processed the data and prepared the first analysis; MM and JZ added to this. $\mathrm{MH}$ wrote the first draft of the paper; MM and JZ added to and edited subsequent versions. All authors read and approved the final manuscript.

\section{Ethics approval and consent to participate}

Individual participants and the companies they represent have consented to voluntary participation in the research project.

\section{Consent for publication}

Participants have consented to use the anonymised quotes from the group meetings and individual interviews in subsequent publications, provided that these quotes cannot be traced back to an individual.

\section{Competing interests}

The authors declare that they have no competing interests.

\section{Publisher's Note}

Springer Nature remains neutral with regard to jurisdictional claims in published maps and institutional affiliations.

Received: 31 October 2017 Accepted: 29 March 2018

Published online: 10 April 2018

\section{References}

Abu-Saifan, S. (2012). Social entrepreneurship: definition and boundaries. Technology Innovation Management Review, 2(2).

Arnoldus, M., Van Kuik, J., Hillen, M. \& Verloop, W. (2013). Stimuleren van de social enterprise sector. Ervaringen en lessen uit Europa voor het ministerie van Economische Zaken. https://www.social-enterprise.nl/wp-content/ uploads/2014/01/Stimulansen-voor-de-Social-Enterprise-Sector.pdf. Accessed 19 Aug 2015.

Ballafkih, H, Zinsmeister, J, Meerman, M, Bay, N (2016). Meedoen in Nieuw-West. Amsterdam: Hogeschool van Amsterdam http://www.hva.nl/binaries/content/assets/subsites/kc-be-carem/assets_11/meedoen_in_nieuw-west def_klein.pdf.

Bergh, $\mathrm{P}$, Thorgren, S, Wincent, J. (2011). Entrepreneurs learning together: the importance of building trust for learning and exploiting business opportunities. International Entrepreneurship and Management Journal, 7(1), 17-37.

Blundel, RK, \& Lyon, F. (2015). Towards a 'long view': historical perspectives on the scaling and replication of social ventures. Journal of Social Entrepreneurship, 6(1), 80-102.

Bordalo, P, Coffman, K, Gennaioli, N, Shleifer, A. (2016). Stereotypes. The Quarterly Journal of Economics, 131(4), 17531794.

Bosma, N., Schøtt, Th., Terjesen, S.A., Kew, P. (2016). Global Entrepreneurship Monitor 2015: special topic report on social entrepreneurship. http://gemconsortium.org/report/49542. Accessed 16 June 2016.

Choi, N, \& Majumdar, S. (2013). Social entrepreneurship as an essentially contested concept: opening a new avenue for systematic future research. Journal of Business Venturing, 29(3), 363-376.

Commissie Code Sociale Ondernemingen (2017). Impact First. Code Sociale Ondernemingen. Vastgestelde versie 1.0, Juli 2017. https://www.social-enterprise.nl/files/5614/9855/5734/Nastgestelde_versie_Code_Sociale_ Ondernemingen.pdf. Accessed 21 Aug 2017.

Crawford, JT, Jussim, L, Madon, S, Cain, TR, Stevens, ST. (2011). The use of stereotypes and individuating information in political person perception. Personality and Social Psychology Bulletin, 37(4), 529-542.

Crucke, S, \& Decramer, A. (2016). The development of a measurement instrument for the organizational performance of social enterprises. Sustainability, 8(2), 161. https://doi.org/10.3390/su8020161.

Dacin, PA, Dacin, MT, Matear, M. (2010). Social entrepreneurship: why we don't need a new theory and how we move forward from here. The academy of management perspectives, 24(3), 37-57.

De Laat, MF, Poell, RF, Simons, PRJ, Van der Krogt, FJ (2001). Organiseren van leren op de werkplek. In A Wald, J van der Linden (Eds.), Leren in perspectief, (pp. 69-84). Apeldoorn: Garant.

Defourny, J (2014). Social enterprise and the third sector: changing European landscapes in a comparative perspective. Abingdon: Routledge.

Defourny, J, \& Nyssens, M. (2010). Conceptions of social enterprise and social entrepreneurship in Europe and the United States: convergences and divergences. Journal of social entrepreneurship, 1(1), 32-53.

Doherty, B, Haugh, H, Lyon, F. (2014). Social enterprises as hybrid organizations: a review and research agenda. International Journal of Management Reviews, 16(4), 417-436.

Estrin, S, Korosteleva, J, Mickiewicz, T. (2013). Which institutions encourage entrepreneurial growth aspirations? Journal of Business Venturing, 28(4), 564-580.

European Commission (2014). A map of social enterprises and their eco-systems in Europe. Synthesis report. http://ec. europa.eu/social/BlobServlet?docld=12987\&langld=en. Accessed 21 Aug 2015. 
European Commission. (2015). How can policy makers improve their country's support to social enterprises? European Policy Brief https://ec.europa.eu/research/social-sciences/pdf/policy_briefs/efeseiis_pb-1115.pdf\#view= fit\&pagemode=none. Accessed 21 June 2016.

Fossati, EC, Degavre, F, Nyssens, M. (2017). How to deal with an "essentially contested concept" on the field? Sampling social innovations through the Delphi method. European Public \& Social Innovation Review, 2(1), 45-58.

Gawell, M. (2014). Social entrepreneurship and the negotiation of emerging social enterprise markets: re-considerations in Swedish policy and practice. International Journal of Public Sector Management, 27(3), 251-266.

Gemeente Amsterdam (2015a). Werkplan Sociale Firma's. https://www.amsterdam.nl/ondernemen/inkoop-aanbesteden/ socialefirmas/beleidsocialefirmas/\#h1f6d63d9-9a89-4afc-9823-5a2e78240130. Accessed 12 Oct 2016.

Gemeente Amsterdam (2015b). Jaarboek Amsterdam in Cijfers 2015. http://www.ois.amsterdam.nl/assets/pdfs/ 2015\%20jaarboek\%20amsterdam\%20in\%20cijfers.pdf. Accessed 2 Feb 2017.

Gemeente Amsterdam (2016). Leidraad Social Return 2016. Stedelijk Bureau Social Return. https://www.cirkelstad.nl/ wp2/wp-content/uploads/2016/03/sroi-inkoop.pdf. Accessed 3 Feb 2017.

Gupta, VK, Turban, DB, Wasti, SA, Sikdar, A. (2009). The role of gender stereotypes in perceptions of entrepreneurs and intentions to become an entrepreneur. Entrepreneurship Theory and Practice, 33(2), 397-417.

Hogenstijn, M (2017). Samen sociaal en ondernemend. Amsterdam: Hogeschool van Amsterdam.

Hogenstijn, M., Zinsmeister, J., Sander, J. \& Meerman, M. (2016). In geouwehoer kun je niet werken. Eindrapport Leernetwerk Sociaal Ondernemerschap en Omgaan met de Overheid - pilot Amsterdam Nieuw-West. http://www. hva.nl/binaries/content/assets/subsites/kc-be-carem/assets_11/eindrapport-leernetwerk-sooo-nieuw.pdf.

Judd, CM, \& Park, B. (1993). Definition and assessment of accuracy in social stereotypes. Psychological Review, 100(1), 109-128.

Jussim, L, Crawford, JT, Rubinstein, RS. (2015). Stereotype (in)accuracy in perceptions of groups and individuals. Current Directions in Psychological Science, 24(6), 490-497.

Keizer, A, Stikkers, A, Heijmans, H, Carsouw, R, Van Aanholt, W (2016). Scaling the impact of the social enterprise sector. McKinsey \& Company http://www.mckinsey.com/industries/social-sector/our-insights/scaling-the-impact-of-thesocial-enterprise-sector. Accessed 2 Nov 2016.

Kickul, J, \& Lyons, TS (2016). Understanding social entrepreneurship: the relentless pursuit of mission in an ever changing world, (2nd ed., ). Abingdon: Routledge.

Korosec, RL, \& Berman, EM. (2006). Municipal support for social entrepreneurship. Public Administration Review, 66(3), $448-462$.

Kraus, S, Filser, M, O'Dwyer, M, Shaw, E. (2014). Social entrepreneurship: an exploratory citation analysis. Review of Managerial Science, 8(2), 275-292.

Kunda, Z, \& Thagard, P. (1996). Forming impressions from stereotypes, traits, and behaviors: A parallel-constraintsatisfaction theory. Psychological review, 103(2), 284

Major, B, \& O'Brien, LT. (2005). The social psychology of stigma. Annual Review of Psychology, 56, 393-421.

Martin, RL, \& Osberg, S (2007). Social entrepreneurship: the case for definition (vol. 5, no. 2, pp. 28-39). Stanford: Stanford social innovation review.

McGovern, P. (2006). Learning networks as an aid to developing strategic capability among small and medium-sized enterprises: a case study from the Irish polymer industry. Journal of Small Business Management, 44(2), 302-305.

Ministerie van Sociale Zaken en Werkgelegenheid (2016). Kabinetsreactie SER advies sociale ondernemingen. https:// www.ser.nl/ /media/files/internet/kabinets\%20reactie/2016/sociale-ondernemingen.ashx. Accessed 4 July 2016.

Oetelmans, E (2015). Actieprogramma sociaal ondernemen 2015-2018. Amsterdam, dé plek voor sociaal ondernemen. Amsterdam: Gemeente Amsterdam https://www.social-enterprise.nl/files/3514/5587/4034/Actieprogramma_ Sociaal_Ondernemen_Amsterdam.pdf. Accessed 19 Oct 2015.

Penman, J, \& Ellis, B. (2003). Mutualism in Australian regional university-community links: the Whyalla experience. Queensland Journal of Educational Research, 19(2), 119-136. http://www.iier.org.au/qjer/qjer19/penman.html.

People's Party for Freedom and Democracy (WD), Christian Democratic Alliance (CDA), Democrats '66 (D66) and Christian Union (CU). (2017). Confidence in the future. 2017-2021 coalition agreement. Document AVT17/ AZ124020. https://www.government.nl/documents/publications/2017/10/10/coalition-agreement-confidence-inthe-future. Accessed 20 Feb 2018.

Peredo, AM, \& McLean, M. (2006). Social entrepreneurship: a critical review of the concept. Journal of World Business, $41(1), 56-65$.

Prothro, ET, \& Melikian, LH. (1955). Studies in stereotypes: V. Familiarity and the kernel of truth hypothesis. The Journal of Social Psychology, 41(1), 3-10.

Ridley-Duff, R, \& Bull, M (2015). Understanding social enterprise: theory and practice. London: Sage.

Schulz, M, Van der Steen, M, Van Twist, M (2013). De koopman als dominee: sociaal ondernemerschap in het publieke domein. Den Haag: Boom Lemma https://www.nsob.nl/wp-content/uploads/2015/08/W.-De-koopman-alsdominee_compleet.pdf. Accessed 21 Aug 2015.

Sepulveda, L. (2015). Social enterprise-a new phenomenon in the field of economic and social welfare? Social Policy \& Administration, 49(7), 842-861.

SER (Sociaal Economische Raad). (2015). Sociale ondernemingen: een verkennend advies. Advies 15/03, mei 2015 https://www.ser.nl/ /media/db_adviezen/2010_2019/2015/sociale-ondernemingen.ashx. Accessed 19 Aug 2015.

Smeets, DJA. (2017). Collaborative learning processes in social impact bonds: a case study from the Netherlands. Journal of Social Entrepreneurship, 8(1), 67-87.

Social Enterprise NL (2015). De Social Enterprise Monitor 2015. http://social-enterprise.nl/wp-content/uploads/2015/05/ Social_Enterprise_NL-monitor_2015-digitaal.pdf. Accessed 3 Aug 2015.

Stephan, U, Uhlaner, LM, Stride, C. (2015). Institutions and social entrepreneurship: the role of institutional voids, institutional support, and institutional configurations. Journal of International Business Studies, 46(3), 308-331.

Teasdale, S. (2012). What's in a name? Making sense of social enterprise discourses. Public policy and administration, $27(2), 99-119$ 
Tell, J, \& Halila, F. (2001). A learning network as a development method-an example of small enterprises and a university working together. Journal of Workplace Learning, 13(1), 14-23.

Terjesen, S, Bosma, N, Stam, E. (2016). Advancing public policy for high-growth, female, and social entrepreneurs. Public Administration Review, 76(2), 230-239.

Wenger, E, Trayner, B, De Laat, M (2011). Promoting and assessing value creation in communities and networks: a conceptual framework, (pp. 202010-202011). Ruud de Moor Centrum: The Netherlands.

Zinsmeister, J (2012). Oud is wijs genoeg. Een studie naar de inzet van de arbeidsvermogens van oudere werknemers. Amsterdam: CAREM/Hogeschool van Amsterdam http://repository.ubn.ru.n//bitstream/handle/2066/111761/111761.pdf.

Submit your manuscript to a SpringerOpen ${ }^{\circ}$ journal and benefit from:

- Convenient online submission

- Rigorous peer review

- Open access: articles freely available online

- High visibility within the field

- Retaining the copyright to your article

Submit your next manuscript at $>$ springeropen.com 